\title{
Abundance, Richness, Seasonal and Altitudinal Dynamics of Aquatic True Bugs (Heteroptera) in Mountain Wetlands of Argentina
}

\author{
E. E. Scheibler ${ }^{1,3}$ - M. C. Melo ${ }^{2,3}$ - S. I. Montemayor ${ }^{2,3}$ • A. M. Scollo ${ }^{1,3}$
}

Received: 8 July 2015 / Accepted: 7 January 2016

(C) Society of Wetland Scientists 2016

\begin{abstract}
Mountain wetlands provide unique information because their biota is highly specific and contributes significantly to regional diversity. The goals of this study were assessing altitudinal and temporal variation in the distribution of Heteropteran assemblages in mountain wetlands; and studying the phenology of the most abundant species. All stages of Heteroptera and data on environmental variables were collected monthly over one year from five mountain wetlands. A simple community structure, and also a low richness of aquatic true bugs, composed of four Heteropteran families (Corixidae, Belostomatidae, Notonectidae and Gelastocoridae), characterized our ponds. Richness and abundance varied temporally and spatially $(p<0.0001)$; and increased at higher elevations. Additionally, the highest abundance of cold stenothermal species occurred at the highest altitudes where harsh conditions are prevalent. Ectemnostega (E.) quadrata and $S$. (T.) jensenhaarupi, both endemic to the Andes region, were the most abundant species. Both these species showed univoltine cycles and overwintered as adults. Biodiversity of the Heteroptera reached maximum values in summer when water temperature increased. Temporal and spatial monitoring studies provide key information on the
\end{abstract}

E. E. Scheibler

escheib@mendoza-conicet.gob.ar

1 Laboratorio de Entomología, IADIZA, CCT CONICET Mendoza, Avda. Ruiz Leal s/n. Parque Gral. San Martín, CC 507, 5500 Mendoza, Argentina

2 División Entomología, Facultad de Ciencias Naturales y Museo, Universidad Nacional de La Plata, Paseo del Bosque s/n, $1900 \mathrm{La}$ Plata, Argentina

3 Consejo Nacional de Investigaciones Científicas y Técnicas (CONICET), Buenos Aires, Argentina distribution, diversity, and habitat requirements of Heteropteran species as well as on conservation and management of these vulnerable habitats and species which are faced with climate warming.

Keywords Aquatic heteropteran communities · Phenology · High-mountain ponds $\cdot$ Arid environment

\section{Introduction}

Small wetlands have been highlighted as extremely important habitats because they host a high and unique biodiversity (Oertli et al. 2008), which contributes significantly to regional biodiversity (Williams et al. 2004). In recent years, many studies have focused on them because of their importance as reservoirs for rare species, in many cases endemic (Biggs et al. 2005), and because they are highly vulnerable to climate change. These environments represent unique areas and are used as sentinel systems (De Meester et al. 2005) to detect and assess global warming and its consequences, since climate changes rapidly with height over relatively short horizontal distances (Ruml and Vulić 2005). Thus, high-altitude wetlands are ideal as model systems because of their small size, simple community structure and low taxonomic richness (De Meester et al. 2005).

Phenological studies may provide key information to understand the effects of climate change on ecology, forestry, agriculture and human health (Van Vliet and Schwartz 2002), for they reflect shifts in the timing of different phenological phases (Ruml and Vulić 2005). Very few studies have been performed analyzing temporal variations in macroinvertebrate communities in temporary and permanent ponds (Scheibler and Ciocco 2011; Mereta et al. 2012; Fontanarrosa et al. 2013; Karaouzas et al. 2015). 
Among aquatic invertebrates, the Heteroptera (Hemiptera) are a particularly interesting group to study because they possess great plasticity to inhabit a variety of environments, such as saline ponds, high mountain wetlands, hot springs, and large rivers (Polhemus 2008). But little is known about the altitudinal distribution ranges of aquatic Heteropteran diversity and even less about their life cycle in the Andes Mountains. The scarce information available comes almost exclusively from old surveys (Macán 1954; Schnack 1976; Bachmann 1981; Savage 1990; Tully et al. 1991); and from ponds affected by salinity (Scheibler and Ciocco 2011, 2013).

The main goals of this study were to assess spatial and temporal variations in the distribution and composition of true bugs in five mountain wetlands following an altitudinal gradient; and to contribute to increasing the knowledge of the life cycle of Sigara (T.) jensenhaarupi (Jaczewski) and Ectemnostega (E.) quadrata (Signoret) (Corixidae), endemic species and the most abundant aquatic true bugs found in high-altitude mountain ponds.

\section{Materials and Methods}

In order to accomplish the goals of the study, we selected five sampling sites following an altitudinal gradient. Sampling was carried out monthly over a complete annual cycle and, to characterize each pond, we measured eleven environmental variables on a monthly basis. To investigate variations in biotic variables, a GLM analysis was performed using month and sampling site as factors. To evaluate how Heteropteran communities and environmental variables were correlated with altitude, we used a Spearman's correlation test. For the description of the phenology of $E$. (E.) quadrata and $S$. (T.) jensenhaarupi, we quantified immature and adult specimens of each species.

\section{Study Area}

Five sampling sites were selected following an altitudinal gradient in the northwest of Mendoza Province, Argentina: (i) Horcones Lake (HO); (ii) Tambillos Dam (TAM); (iii) Upward Uspallata (UU); (iv) Downward Uspallata (DU), and (v) Potrerillos (PO) (Fig. 1). All sampling sites are located along the longitudinal gradient of the Mendoza River basin $\left(18,484 \mathrm{~km}^{2}\right)$, and are representative of mountain wetlands in the Andes Mountains of Central Argentina, covering two biogeographical provinces (Andean and Monte, Morrone 2006). The Mendoza River basin is located in Argentina's Central Andes in the north of Mendoza Province $\left(32^{\circ} 00^{\prime}-37^{\circ} 35^{\prime} \mathrm{S}\right.$; $66^{\circ} 30^{\prime}-70^{\circ} 35^{\prime} \mathrm{W}$ ) (Fig. 1). This watershed is mostly fed by snow melt from the Andes Mountains. Snowfall is the predominant water input to the Andes mountain range. Rainfalls occur in spring and summer, though their contribution to the
Mendoza River is insignificant. The regional climate can be defined as arid, of maximum continentality and typically temperate (Departamento General de Irrigación 2006).

The water bodies studied (Fig. 1) were represented by 1) Horcones Lake: a glacial and permanent lake located at the highest altitude (2981 m asl), included as a RAMSAR site, placed in Aconcagua Provincial Park $\left(710 \mathrm{~km}^{2}\right)$ in the High Andes region (Mount Aconcagua $6962 \mathrm{~m}$ a.s.l.) on the Cordillera Principal. Horcones Lake was characterized by a great abundance of Chara sp. (algae) and riparian vegetation formed by Carex aff. Gayana and Schoennoplectus pungens. 2) Tambillos Dam: a permanent dam lying at high elevation (2458 m asl) on the Cordillera Frontal in the Andean province, fed by the Tambillos stream and with dominance of Chara sp. Riparian vegetation was composed of Larrea nitida. 3 and 4) Upward Uspallata and Downward Uspallata: the third and fourth sampling sites are connected to the Uspallata River, a permanent tributary of the Mendoza River, located in the depression of Uspallata Valley, between the Cordillera Frontal and the Precordillera. Both sampling sites presented macrophytes, which were absent in the rest of the sampling sites. Riparian vegetation was represented by Cortaderia rudiuscula, Proustia cuneifolia and Tessaria absinthioides. 5) Potrerillos: the last sampling site is situated in the Precordillera and is fed by the Mendoza River. Sampling was performed on the banks of the dam, in an area with abundant poplar trees (Populus sp., Salicaceae) which belonged to a former camping ground, which was flooded by the river when the Potrerillos Dam was built. Annual rainfall during the study period was $224.4 \mathrm{~mm}$ at Potrerillos locality (PO) and $248.2 \mathrm{~mm}$ at Polvaredas (2286 m asl, close to Horcones Lake) (HO) with a rainfall peak occurring in January at Potrerillos $(26.5 \mathrm{~mm})$ and in May at Polvaredas $(30 \mathrm{~mm})($ data provided by Secretaría de Recursos Hídricos, Argentina). The main characteristics of the ponds studied are specified in Table 2.

\section{Sampling}

Sampling was carried out monthly over a complete annual cycle, between October 2007 and September 2008. January and February (summer) were sampled twice, because these are the months when abundance of the Heteroptera reaches its peak (Bachmann 1981), and we wanted to asses abundance for each stage of Heteropteran species. Three replicates of each sample were taken in each pond, by thoroughly sweeping with a hand net (mesh size $=500 \mu \mathrm{m}$ ) across the various habitats. Total sampling time was $60 \mathrm{~min}$ for each pond. Samples collected in the field were preserved in $95 \%$ ethanol and deposited in the National Collection of the Entomology Laboratory of IADIZA-CCT CONICET Mendoza, voucher specimens were deposited at the Museo de La Plata, Buenos Aires, Argentina. 
Fig. 1 Map of study area indicating sampling sites following an altitudinal gradient

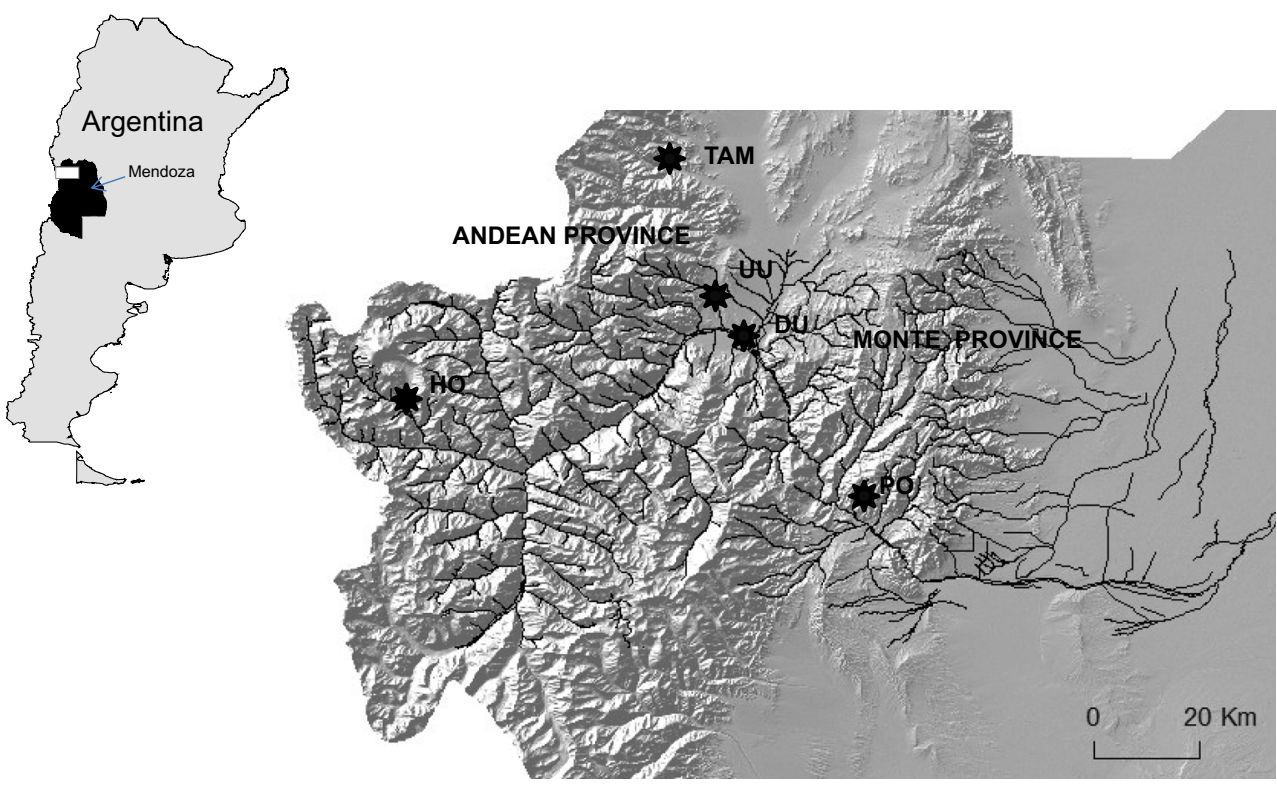

Finally, to characterize each pond, we measured monthly the following environmental variables: conductivity $\left(\mu \mathrm{S} \mathrm{cm}{ }^{-1}\right.$; Hanna conductivity meter HI 9033), pH (Hanna pH meter, HI 9025), transparency (m; Secchi disk), water and air temperature $\left({ }^{\circ} \mathrm{C}\right.$; mercury thermometer), depth $(\mathrm{m}$; calibrated stick), environmental humidity (\% Hygrotherm HT05), \% Oxygen saturation $\left(\% \mathrm{O}_{2}\right.$, Hach Dissolved Oxygen meter), pond area $\left(\mathrm{m}^{2}\right)$, macrophyte/algal richness and type of substrate.

In the winter months, HO (from June to September 2008) and TAM (from June to July 2008) could not be sampled because the ponds were frozen. PO was sampled in October 2007, February 2007, and from March to August 2008 because of its temporary nature.

\section{Data Analysis}

Abundance and richness were calculated for each sample and, for this purpose, a data matrix was constructed with biotic variables (number of individuals: larvae and adults of each taxon) for each replicate, month and sampling site, over a complete annual cycle (2007-2008).

To investigate variations in biotic variables (total abundance, abundance and richness of each species), a temporal analysis was performed using month (M) as a factor, and a spatial analysis using sampling site (SS) as a factor. Discrete data (abundance) was analyzed using Poisson distribution with logarithm as link function, and tested with $X^{2}$. Because residual errors in the model showed over-dispersion (i.e., residual deviance was higher than the degree of freedom of the residual), the model was rescaled to correct for biases in the statistical test of hypotheses (Crawley 1993), using F tests instead of $X^{2}$ as a measure of fit. Detailed procedures for this type of analysis can be found in Crawley (1993) and
McConway et al. (1999). For this analysis we used Generalized Linear Models (GLM; GENSTAT software, version 4.2, 2005). Using GLM analyses, we also estimated the percent variation explained by the model for each biotic response variable as follows: $\%$ of explained variability $=\mathrm{ex}-$ plained deviance/total deviance $\times 100$.

To know the correlation levels between altitude and structure of Heteroptera (total species richness and total abundance), and between altitude and physicochemical variables, we performed a Spearman's correlation test. Only those Spearman's correlation coefficients $($ rho $=\delta$ ) showing $p \leq 0.05$ were considered to be significant.

To describe the phenology of $E$. (E.) quadrata and $S$. (T.) jensenhaarupi, we quantified immature and adult specimens of each species. To separate each instar, we followed Scheibler and Melo (2010) and Melo and Scheibler (2011). The individuals counted for life history descriptions were: 1021 nymphs and 283 adults of $E$. (E.) quadrata, and 2087 nymphs and 875 adults of $S$. (T.) jensenhaarupi.

\section{Results}

\section{Environmental Variables and Pond Characterization}

Water temperature ranged from $2.9^{\circ} \mathrm{C}$ (in May at TAM) to $25.1^{\circ} \mathrm{C}$ (in April at DU). Minimum water depth was $0.04 \mathrm{~m}$ (in November at UU), and maximum water depth was $1.1 \mathrm{~m}$ (in January at TAM). Humidity varied from $14 \%$ (during November) to $83 \%$ (during February). Minimum conductivity was $115 \mu \mathrm{S} \mathrm{cm}^{-1}$ (in January at TAM), maximum conductivity was $1700 \mu \mathrm{S} \mathrm{cm}^{-1}$ (in October at $\mathrm{PO}$ ), and $\mathrm{pH}$ varied between 6.67 and 9.72 (Table 2). 
HO sampling site exhibited higher conductivity values, alkaline $\mathrm{pH}$, and substrate composed mostly of sand and silt. TAM sampling site was linked to presence of cobble and pebble substrate, higher transparency and depth, and the lowest conductivity values. Both sampling sites had presence of algae (Chara sp. and Cladophora sp.) and maximal oxygen saturations values (Table 2). UU and DU were the only sites showing presence of macrophytes. UU was also characterized by presence of cattle and human urbanization. Conductivity values increased almost twice at DU with respect to UU. The area is surrounded by farms that dump their wastes into the Uspallata River, therefore polluting the ponds. PO was a temporary site with absence of macrophytes and with the highest values of conductivity, which showed long periods of dryness depending on the water provided by the Mendoza River. The area is very urbanized as it is near the Potrerillos Dam where recreational activities are performed. Environmental characteristics of the sampling sites studied are provided in Table 2.

\section{Richness, Distribution and Monthly Variations in the Heteroptera}

During the annual sample period (2007-2008), we collected 4332 specimens (nymphs and adults) belonging to four families of Heteroptera (Corixidae, Notonectidae, Belostomatidae and Gelastocoridae) (Table 1). Corixidae were found at all sampling sites. Gelastocoridae showed the lowest abundance and was present only at TAM and UU; Belostomatidae and Notonectidae were only found at UU and TAM, respectively. Total abundance varied among sampling sites $\left(\mathrm{F}_{4-176}=79.78 ; p<0.001 ; \%\right.$ of explained variability $=44)$, ranging from one species $(E$. (E.) quadrata) at $\mathrm{HO}$ to five species at TAM and UU (Table 1). Although these two sites showed the highest richness of Heteroptera, they differed in total abundance: TAM had 2610 specimens, and UU 405 specimens (Fig. 2a-b). On the other hand, DU and PO were the sites with the least abundance and richness (DU: 2 species, 9 specimens; PO: 2 species, 3 specimens) (Fig. 2a-b).

Ectemnostega (E.) quadrata and $S$. (T.) jensenhaarupi were the species with the highest abundance all along the sampled year (Tables 1 and 2). Total abundance showed also significant differences among months $\left(\mathrm{F}_{13-176}=18.75 ; p<0.001 ; \%\right.$ of explained variability $=33$ ), the highest abundance was registered during summer (mainly December-February) (Fig. 3a); maximum abundance also matched the highest records of air and water temperature (Figs. 4 and 5). Total richness showed more significant differences among sampling sites $\left(\mathrm{F}_{4-176}=32.68 ; p<0.001 ; \%\right.$ of explained variability $\left.=37\right)$ than among months $\left(\mathrm{F}_{13-176}=4.54 ; p<0.001 ; \%\right.$ of explained variability $=17$ ). January and March were the months with the highest species richness (Fig. 3b).

Altitude showed significant correlations with physicochemical variables: pH (Spearman $\delta=0.66$ $\mathrm{p}=<0.0001)$, transparency (Spearman $\delta=0.33$ $\mathrm{p}=<0.0001)$, pond area (Spearman $\delta=0.36$ $\mathrm{p}=<0.0001)$, and also with biotic variables: total species abundance (Spearman $\delta=0.69 \mathrm{p}=<0.0001$ ), and total species richness (Spearman $\delta=0.57 \mathrm{p}=<0.0001$ ). Nevertheless, it showed a negative correlation with conductivity (Spearman $\delta=-0.43 \mathrm{p}=<0.0001$ ).

Table 1 Total individuals and standard deviation (in parentheses) of Heteropteran species collected from each sampling site in Mendoza wetlands

\begin{tabular}{|c|c|c|c|c|c|}
\hline Species/Sampling sites & $\mathrm{HO}$ & TAM & $\mathrm{UU}$ & DU & $\mathrm{PO}$ \\
\hline \multicolumn{6}{|l|}{ Corixidae } \\
\hline Sigara (Tropocorixa) jensenhaarupi Jaczewski & 0 & $2595(64.1)$ & $358(12.17)$ & $7(0.7)$ & $2(0.38)$ \\
\hline Sigara (Tropocorixa) femoridens Hungerford & 0 & 0 & 0 & $2(0.31)$ & 0 \\
\hline Sigara sp. & 0 & 0 & 0 & 0 & $1(0.19)$ \\
\hline Ectemnostega quadrata Signoret & $1304(42.05)$ & $2(0.33)$ & 0 & 0 & 0 \\
\hline \multicolumn{6}{|l|}{ Belostomatidae } \\
\hline Belostoma elegans Mayr & 0 & 0 & $8(0.71)$ & 0 & 0 \\
\hline Belostoma sp. & 0 & 0 & $38(2.45)$ & 0 & 0 \\
\hline \multicolumn{6}{|l|}{ Gelastocoridae } \\
\hline Nerthra ranina Herrich-Schaeffer & 0 & 0 & $1(0.15)$ & 0 & 0 \\
\hline Nerthra sp. & 0 & $2(0.23)$ & $1(0.15)$ & 0 & 0 \\
\hline \multicolumn{6}{|l|}{ Notonectidae } \\
\hline Notonecta (Paranecta) peruviana Hungerford & 0 & $3(0.5)$ & 0 & 0 & 0 \\
\hline Notonectidae sp. & 0 & $8(0.87)$ & 0 & 0 & 0 \\
\hline Total abundance & 1304 & 2610 & 406 & 9 & 3 \\
\hline
\end{tabular}

References: HO: Horcones Lake; TAM: Tambillos Dam; UU: Upward Uspallata; DU: Downward Uspallata and PO: Potrerillos Dam 
Fig. 2 Mean and standard error in a) abundance (larvae and adults) of Heteroptera and b) richness of Heteroptera for the five mountain ponds. References: HO: Horcones Lake; TAM: Tambillos Dam; UU: Upward Uspallata; DU: Downward Uspallata and PO: Potrerillos Dam
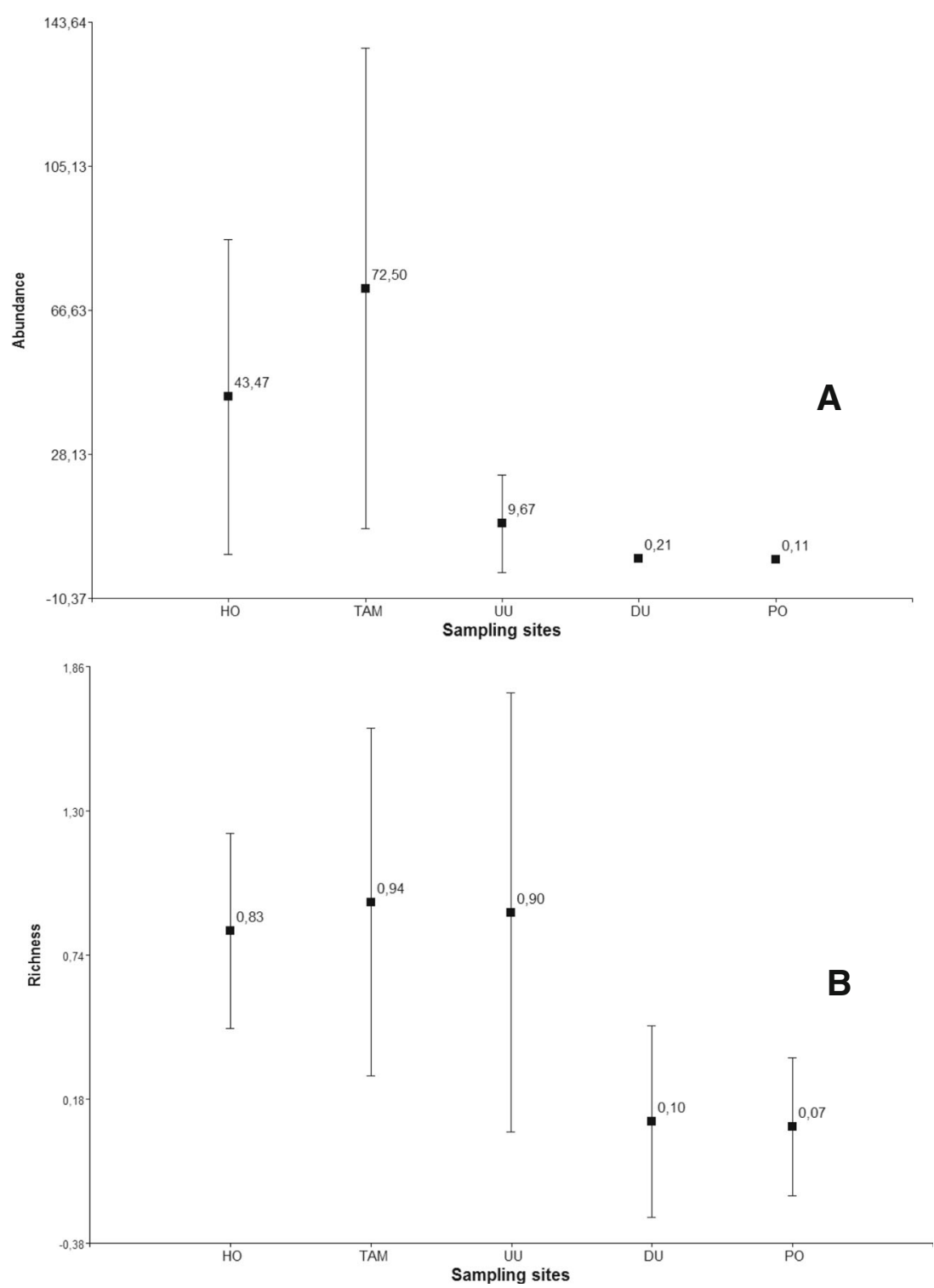

\section{Phenology, Spatial and Temporal Variations of E. (E.)} Quadrata and S. (T.) Jensenhaarupi

Our data demonstrate a restricted distribution of $E$. (E.) quadrata, which was only present at highest elevations, whereas $S$. (T.) jensenhaarupi showed a broader distribution, as it was found at four of the five sampling sites. We conclude that both species have a univoltine life cycle. Early instars of E. (E.) quadrata (1, 2 and 3) began to appear in December with a peak in this month; instar 3 had another peak in January, instar 4 in February, followed by instar 5 with a peak in March. Growth was faster during the summer (DecemberMarch). Adults increased in abundance in April and May, with maximum densities in October. During winter (JuneSeptember), the lake is frozen so the higher abundance of adults in October indicates that this is the overwintering stage (Fig. 4). In the case of $S$. (T.) jensenhaarupi, early instars (1,2 and 3) began to appear in December, when water temperature increased, showing low densities; instars 2 and 3 had a peak in February and March; instar 4 had a peak in December, and instar 5 showed a peak in January. From June to November, the density of immature stages was zero. Only adults were able to pass through the winter and early spring (Fig. 5).

\section{Discussion}

\section{Species Richness}

In agreement with observations of De Meester et al. (2005), the mountain ponds studied showed a simple community structure and also a low richness of Heteroptera. Four families of Heteroptera were found: Corixidae, Belostomatidae, 


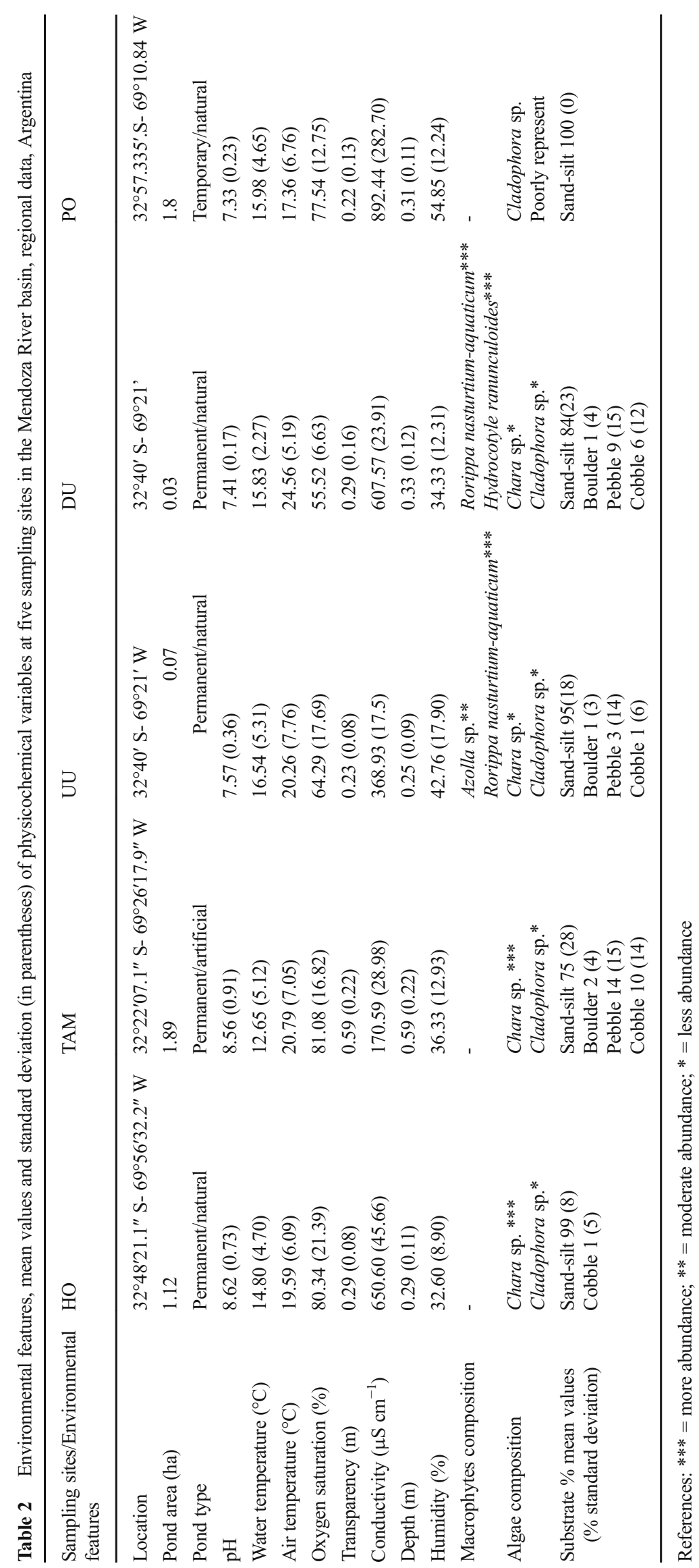


Fig. 3 Mean and standard error in (a) abundance (larvae and adults) and (b) richness of Heteroptera over an annual cycle (monthly variation)
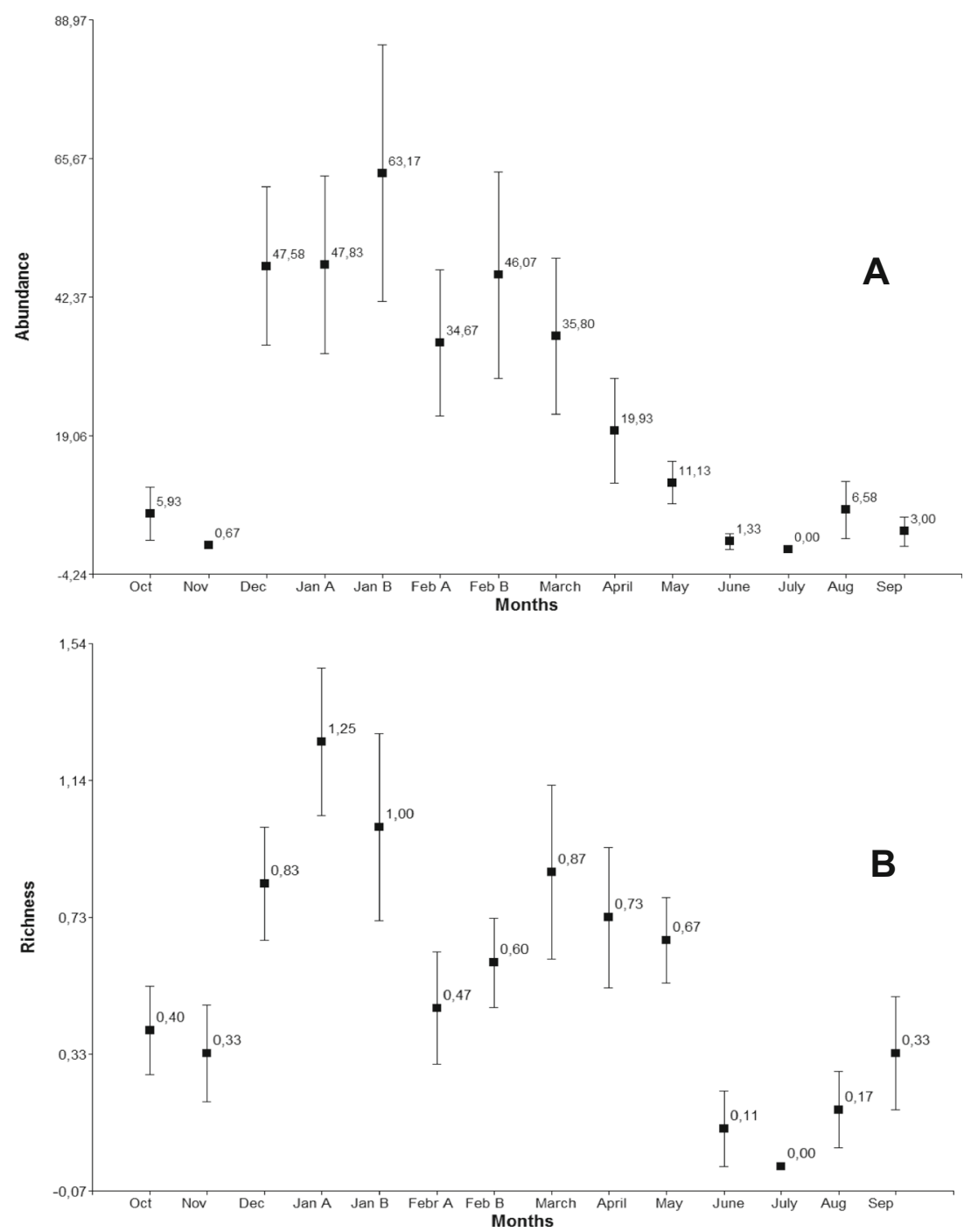

Notonectidae and Gelastocoridae; among them, the most abundant was Corixidae. Ectemnostega (E.) quadrata and $S$. (T.) jensenhaarupi (Corixidae) were the most abundant ones; both are endemic to the Andean region. This is important because the highest mountain wetlands are known to be reservoirs for rare species (Biggs et al. 2005).

Previous studies highlight altitude, $\mathrm{pH}$, conductivity and presence of macrophytes as important environmental variables clearly correlated with species richness (Oertli et al. 2000, 2008; Hinden et al. 2005). Our results confirmed their observations regarding $\mathrm{pH}$, conductivity, and macrophytes. A decrease in $\mathrm{pH}$ is correlated with a decrease in species richness, a decrease in conductivity is correlated with an increase in species richness, and macrophytes are relevant drivers of species richness (Ilg and Oertli 2014). On the other hand, and in contradiction to previous studies, we observed that there is a positive correlation between species richness and high altitude that can be explained by the positive correlation observed among altitude, alkaline and transparent waters, and largest pond area. Despite being the highest pond, HO site did not follow the same pattern for it showed the lowest richness. This is because it is the sole site that is not fed by any tributary, is frozen during all of the winter, and shows increased conductivity. Oertli et al. (2008) had shown that presence of a tributary significantly increases the number of taxa in ponds. The presence of ice during winter represents a major obstacle to organisms for they have to cope with low food availability, low temperature, and low nutrient conditions (Sommaruga 2001). In addition, increased levels of conductivity cause decreased species richness (Ilg and Oertli 2014).

\section{Species Abundance}

Annual monitoring made it possible to detect variations in species abundance along the altitudinal gradient. Ectemnostega (E.) quadrata predominated at the highest elevation (2891 m asl), while $S$. (T.) jensenhaarupi was found at different heights $(2458-1350 \mathrm{~m}$ asl); and both 
Fig. 4 Phenological characteristics of Ectemnostega (E.) quadrata from Horcones

Lake

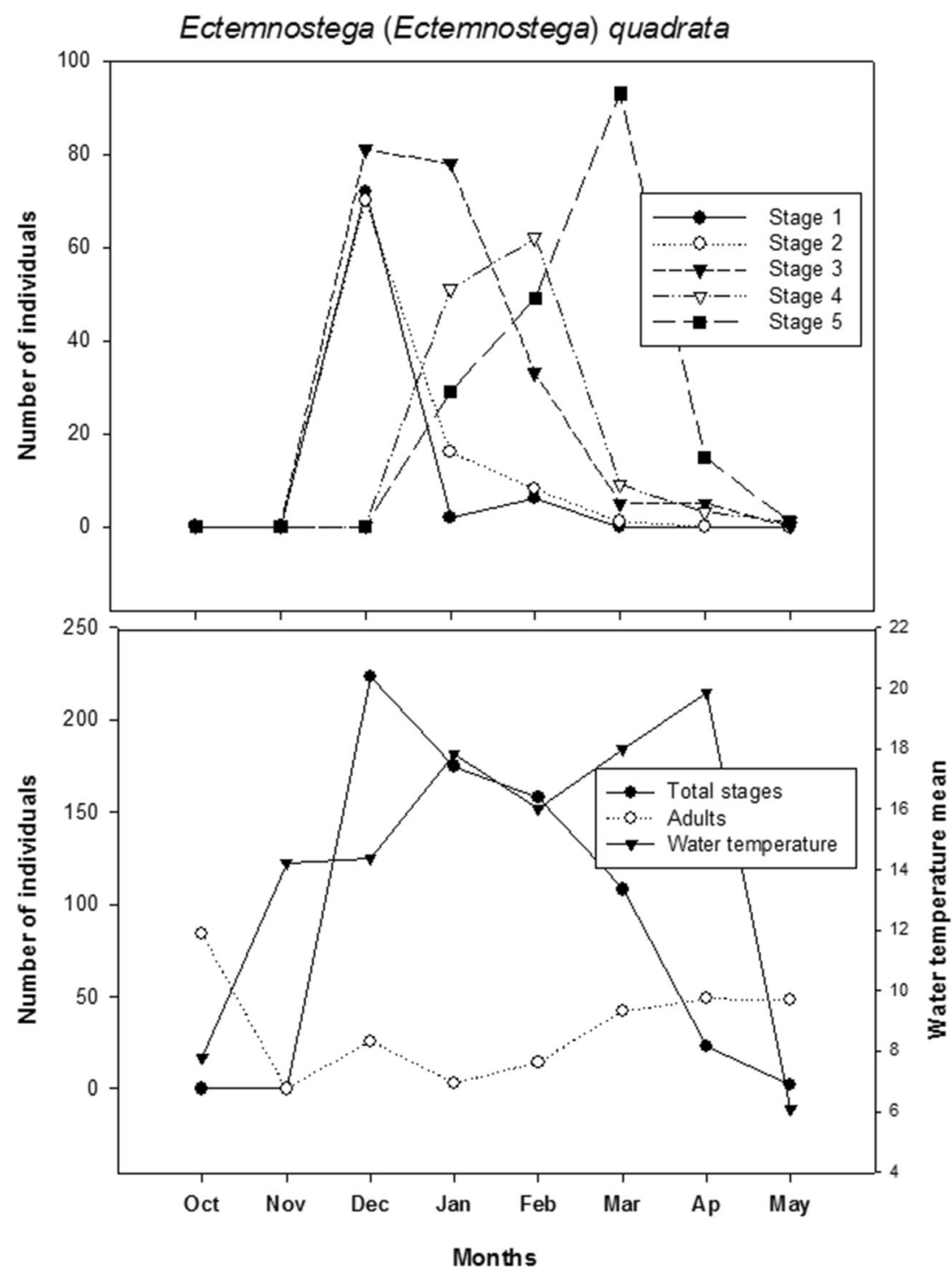

species reached their maximum abundance at the highest elevation of their distributional range (2891 and $2458 \mathrm{~m}$ asl, respectively).

In our study, we observed that the highest abundance occurred at the highest sites, and this result was confirmed by the positive correlation found between total abundance and altitude. This can be due to the fact that sites with higher species abundance are permanent ponds which are largest in size; and a high percentage of open water favors colonization of these environments by corixids (Popham 1943; Bloechl et al. 2010). Moreover, the highest ponds have a great abundance of algae that can be used as both food resource and refuge against predators. The Corixidae family has a particular preference for stable aquatic systems with clear and oxygenated water, with neutral to alkaline $\mathrm{pH}$, a high percentage of open waters, and presence of algae (Tully et al. 1991), all of which conditions are met by our highest mountain wetlands. In conclusion, the environmental conditions found in our highest mountain ponds appear to be suitable for development and survival of these true bugs.

\section{Phenology}

Maximum abundance of true bugs was recorded during summer when the highest water temperature was measured. Moreover, larval stages of $S$. (T.) jensenhaarupi (monitored all year round) were zero in the winter and spring months. Aquatic Heteroptera lay eggs mostly in spring, grow in summer, survive as adults and repeat the cycle of life (Polhemus 2008), all of which is consistent with our observations and results. Corixids can produce one or two generations per year depending on the species or climate (Hungerford 1948). The most abundant species found in our mountain ponds showed univoltine cycles and overwintered as adults. Additionally, the characteristics of the ponds where they were found (long hydroperiod and consequently more stability) make it possible 
Fig. 5 Phenological characteristics of Sigara $(T$.) jensenhaarupi from all sampling sites
Sigara (Tropocorixa) jensenhaarupi

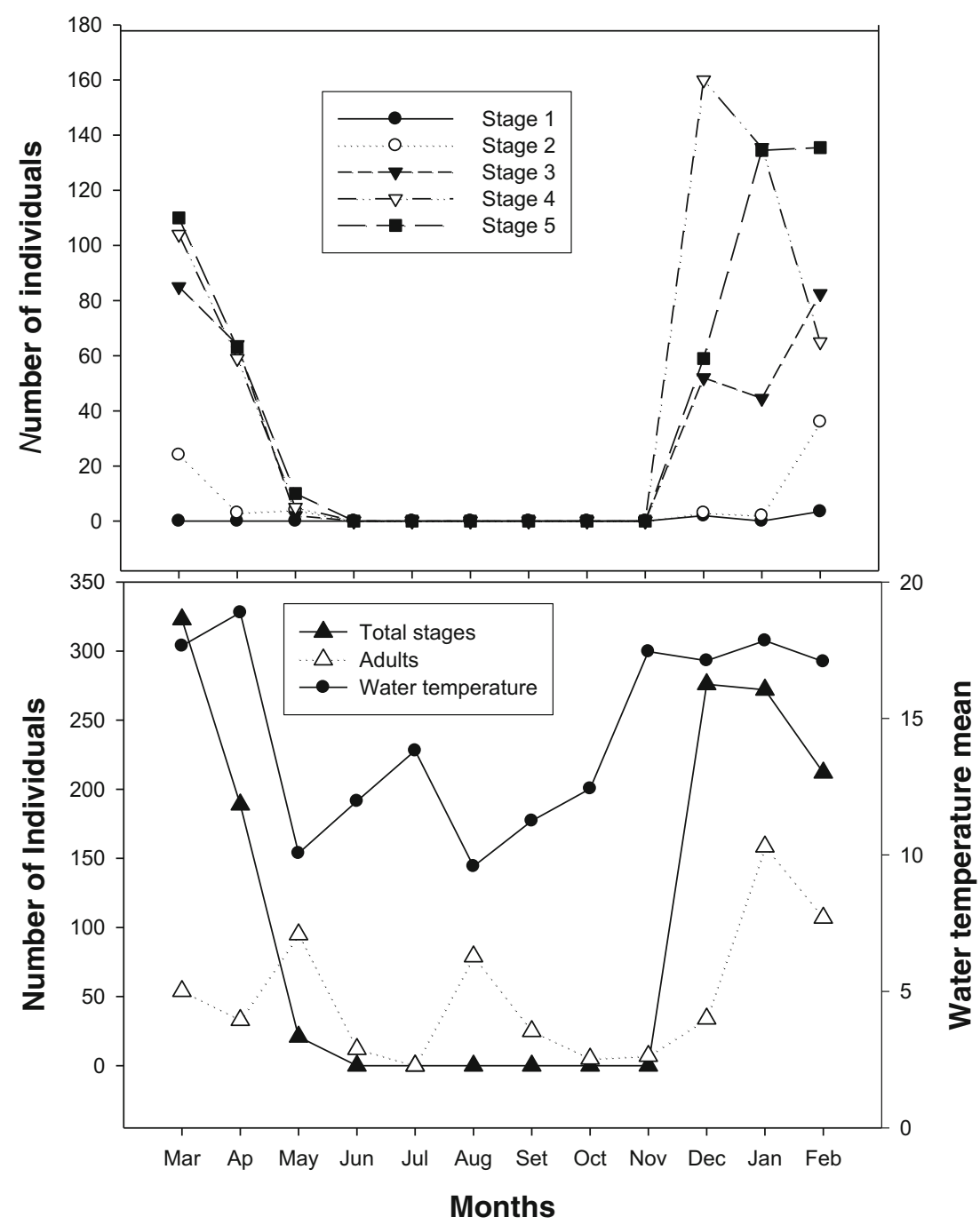

for the species to complete their life cycle at the highest elevations (2891 and $2458 \mathrm{~m}$ asl). However, these Corixidae species produced only one generation per year; but it would be interesting to ascertain whether the number of generations of these Heteropteran species is dependent on climate as we suggest, or if it is an intrinsic characteristic of the species.

The Corixidae family is cold-adapted (Cummins et al. 2008 ) and some of its species are considered to be cold stenothermal, as is the case of E. (E.) quadrata (Bachmann 1981). Ilg and Oertli (2014) found that cold stenothermal species are limited to mountain areas regardless of the harsh environmental conditions prevailing at high altitudes. The highest abundance of cold stenothermal species in our study occurred at the highest altitudes where harsh conditions (higher conductivity values and frozen waters during the winter) prevail, such as occurs in alpine ponds.

These high mountain ponds constitute irreplaceable habitats for a variety of freshwater biota, as they harbor uncommon and endemic species. Our results confirmed that altitude is the most important driver of Heteropteran species diversity. Temporal and spatial monitoring studies provide key information about the distribution, diversity and habitat requirements of Heteropteran species as well as on conservation and management of these vulnerable habitats and species which are faced with climate warming.

Acknowledgments We especially want to thank our colleagues from the Entomology Lab (IADIZA- CCT Mendoza CONICET) for their support during the fieldwork. We are especially grateful to Nélida B. Horak for assistance in the English language and to the Direction of Renewable Natural Resources (Mendoza Government, Ministry of the Environment) for granting the permits for us to conduct the samplings (Resolutions: 552 and 1353). This study was funded by the Consejo Nacional de Investigaciones Científicas y Técnicas (CONICET), Argentina, and the following grants: FONCYT (Fondo para la investigación científica y tecnológica) PICT 2013-1539 and PICT 2014-0488. 


\section{References}

Bachmann AO (1981) Insecta Hemiptera Corixidae. Fauna de Agua Dulce de la República Argentina 35: 1-270.

Biggs J, Williams P, Whitfield P, Nicolet P, Weatherby A (2005) 15 years of pond assessment in Britain: results and lessons learned from the work of pond conservation. Aquatic Conservation: Marine and Freshwater Ecosystems 15:693-714

Bloechl A, Koenemann S, Philippi B, Melber A (2010) Abundance, diversity and succession of aquatic coleoptera and heteroptera in a cluster of artificial ponds in the north German lowlands. Limnologica 40:215-225

Crawley MJ (1993) 'GLIM for ecologist'. Blackwell Scientific Publishing, Oxford

Cummins KW, Merritt RW, Berg MB (2008) Ecology and distribution of aquatic insects. In: Cummins KW, Merritt RW, Berg MB (eds) An introduction to the aquatic insects of North America. Kendall/Hunt Publishing Co., Dubuque, pp. 105-122

De Meester L, Declerck S, Stoks R, Louette G, Van de Meutter F, De Bie T, Michels E, Brendonck L (2005) Ponds and pools as model systems in conservation biology, ecology and evolutionary biology. Aquatic Conservation: Marine and Freshwater Ecosystems 15:715-725

Departamento General de Irrigación (2006) Estudios de caracterización del Sistema hídrico superficial de la provincia de Mendoza. Programa de riego y drenaje de la provincia de Mendoza PROSAPDGI-OEI, Gobierno de Mendoza, Departamento General de Irrigación, Argentina, p. 176.

Fontanarrosa MS, Collantes MB, Bachmann AO (2013) Aquatic insect assemblages of man-made permanent ponds, Buenos Aires city, Argentina. Neotropical Entomology 42:22-31

Hinden H, Oertli B, Menetrey N, Sager L, Lachavanne JB (2005) Alpine pond biodiversity: what are the related environmental variables? Aquatic Conservation: Marine and Freshwater Ecosystems 15:613-624

Hungerford HB (1948) The corixidae of the western hemisphere (hemiptera). The University of Kansas Science Bulletin 32:1-827

Ilg C, Oertli B (2014) How can we conserve cold sthenotherm communities in warming alpine ponds? Hydrobiologia 723:53-62

Karaouzas I, Dimitriou E, Lampou A, Colombari E (2015) Seasonal and spatial patterns of macroinvertebrate assemblages and environmental conditions in Mediterranean temporary ponds in Greece. Limnology 16:41-53

Macán TT (1954) A contribution to the study of the ecology of corixidae (hemiptera). The Journal of Animal Ecology 23:115-141

McConway KJ, Jones MC, Taylor PC (1999) Statistical modelling using GENSTAT. Arnold Publisher, London

Melo MC, Scheibler EE (2011) Description of the immature stages of Sigara (Tropocorixa) jensenhaarupi Jaczewski 1927 (Heteroptera: Corixidae), with ecological notes on the species. Revista Mexicana de Biodiversidad 82:931-944

Mereta ST, Boets P, Bayih AA, Malu A, Ephrem Z, Sisay A, Endale H, Yitbarek M, Jemal A, De Meester L, Goethals PLM (2012) Analysis of environmental factors determining the abundance and diversity of macroinvertebrate taxa in natural wetlands of southwest Ethiopia. Ecological Informatics 7:52-61
Morrone JJ (2006) Biogeographic areas and transition zones of Latin America and the Caribbean Islands based on panbiogeographic and cladistic analyses of the entomofauna. Annual Review of Entomology 51:467-494

Oertli B, Auderset Joye D, Castella E, Juge R, Lachavanne JB (2000) Diversite' biologique et typologie e'cologique des e'tangs et petits lacs de Suisse. Swiss agency for the environment. Laboratory of Aquatic Ecology and Biology (LEBA), University of Geneva, Forests and Landscape

Oertli B, Indermuehle N, Angélibert S, Hinden H, Stoll A (2008) Macroinvertebrate assemblages in 25 high alpine ponds of the Swiss national park (cirque of macun) and relation to environmental variables. Hydrobiologia 597:29-41

Polhemus JT (2008) Aquatic and semiaquatic hemiptera. In: Merrit RW, Cummins KW, Berg MB (eds) An introduction to the aquatic insects of North America. Kendall/Hunt Publishing Co., Dubuque, pp. $385-423$

Popham EJ (1943) Ecological studies of the commoner species of British corixidae. The Journal of Animal Ecology 12:124-136

Ruml M, Vulić T (2005) Importance of phenological observations and predictions in agriculture. The Journal of Agricultural Science 50(2): 217-225

Savage AA (1990) The distribution of corixidae in lakes and the ecological status of the North West midlands meres. Field Studies 7:516530

Scheibler EE, Ciocco NF (2011) Distribution of macroinvertebrate assemblages along a saline wetland in harsh environmental conditions from central-west Argentina. Limnologica 41:3747

Scheibler EE, Ciocco NF (2013) Diversity of aquatic insects and other associated macroinvertebrates in an arid wetland (Mendoza province, Argentina). Revista de la Sociedad Entomológica Argentina 72:41-53

Scheibler EE, Melo MC (2010) Description of immature stages of Ectemnostega (ectemnostega) quadrata (signoret 1885) (Heteroptera: Corixidae), with notes on ecological requirements of the species. Aquatic Insects 32:99-111

Schnack JA (1976) Estimación de parámetros en una población de corixidae (Hemiptera) en base a un modelo estocástico de capturarecaptura. Limnobios 1:1-7

Sommaruga R (2001) The role of solar UV radiation in the ecology of alpine lakes. Journal of Photochemistry and Photobiology B: Biology 62:35-42

Tully O, McCarthy TK, O’Donnell D (1991) The ecology of the corixidae (Hemiptera: Heteroptera) in the Corrib catchment, Ireland. Hydrobiologia 210:161-169

Van Vliet AJH, Schwartz MD (2002) Phenology and climate: the timing of life cycle events as indicators of climatic variability and change. International Journal of Climatology 22:17131714

Williams P, Whitfield M, Biggs J, Bray S, Fox G, Nicolet P, Sear D (2004) Comparative biodiversity of rivers, streams, ditches and ponds in an agricultural landscape in southern England. Biological Conservation $115: 329-341$ 